\title{
Kinetic Investigation of $\mathrm{CO}_{2}-\mathrm{CH}_{4}$ Reaction over $\mathrm{Ni} / \mathrm{La}_{2} \mathrm{O}_{3}$ Catalyst using Photoacoustic Spectroscopy
}

\author{
Hyun-Jin Oh, Jin-Gyu Kang, Eil Heo, ${ }^{\dagger}$ Sung-Han Lee, ${ }^{\dagger, *}$ and Joong-Gill Choi* \\ Department of Chemistry, Yonsei University, Seoul 120-749, Korea. *E-mail: jgchoi@yonsei.ac.kr \\ †Department of Chemistry, Yonsei University, Wonju 220-710, Korea. ${ }^{*}$ E-mail: shl2238@yonsei.ac.kr \\ Received April 2, 2014, Accepted May 1, 2014
}

\begin{abstract}
$\mathrm{Ni} / \mathrm{La}_{2} \mathrm{O}_{3}$ with a high dispersion was prepared by reduction of $\mathrm{LaNiO}_{3}$ perovskite oxide to examine the catalytic activity for the $\mathrm{CO}_{2}-\mathrm{CH}_{4}$ reaction. The $\mathrm{Ni} / \mathrm{La}_{2} \mathrm{O}_{3}$ catalyst was found to be highly active for the reaction. The ratios of $\mathrm{H}_{2} / \mathrm{CO}$ were measured in a flow of the reaction mixture containing $\mathrm{CO}_{2} / \mathrm{CH}_{4} / \mathrm{Ar}$ using an on-line gas chromatography system operated at $1 \mathrm{~atm}$ and found to be varied with temperature between 0.66 and 1 in the temperature range of $500-800{ }^{\circ} \mathrm{C}$. A kinetic study of the catalytic reaction was performed in a static reactor at 40 Torr total pressure of $\mathrm{CO}_{2} / \mathrm{CH}_{4} / \mathrm{N}_{2}$ by using a photoacoustic spectroscopy technique. The $\mathrm{CO}_{2}$ photoacoustic signal varying with the concentration of $\mathrm{CO}_{2}$ during the catalytic reaction was recorded as a function of time. Rates of $\mathrm{CO}_{2}$ disappearance in the temperature range of $550-700{ }^{\circ} \mathrm{C}$ were obtained from the changes in the $\mathrm{CO}_{2}$ photoacoustic signal at early reaction stage. The plot of $\ln$ rate vs. $1 / \mathrm{T}$ showed linear lines below and above $610^{\circ} \mathrm{C}$. Apparent activation energies were determined to be $10.4 \mathrm{kcal} / \mathrm{mol}$ in the temperature range of 550 $610{ }^{\circ} \mathrm{C}$ and $14.6 \mathrm{kcal} / \mathrm{mol}$ in the temperature range of $610-700{ }^{\circ} \mathrm{C}$. From the initial rates measured at $640{ }^{\circ} \mathrm{C}$ under various partial pressures of $\mathrm{CO}_{2}$ and $\mathrm{CH}_{4}$, the reaction orders were determined to be 0.43 with respect to $\mathrm{CO}_{2}$ and 0.33 with respect to $\mathrm{CH}_{4}$. The kinetic results were compared with those reported previously and used to infer a reaction mechanism for the $\mathrm{Ni} / \mathrm{La}_{2} \mathrm{O}_{3}$-catalyzed $\mathrm{CO}_{2}-\mathrm{CH}_{4}$ reaction.
\end{abstract}

Key Words : Kinetic study, $\mathrm{CO}_{2}$ reforming of $\mathrm{CH}_{4}, \mathrm{Ni} / \mathrm{La}_{2} \mathrm{O}_{3}$ catalyst, Photoacoustic spectroscopy

\section{Introduction}

The $\mathrm{CO}_{2}$ reforming of $\mathrm{CH}_{4}, \mathrm{CO}_{2}+\mathrm{CH}_{4} \rightarrow 2 \mathrm{CO}+2 \mathrm{H}_{2}$, has received of great attention because it converts green house gases into a synthesis gas. This reaction produces a synthesis gas with a $\mathrm{H}_{2} / \mathrm{CO}$ molar ratio close to 1 , which is suitable for the production of oxygenated hydrocarbons like methanol and aldehyde. Nickel has been proven to be one of the active catalysts for the $\mathrm{CO}_{2}$ reforming of $\mathrm{CH}_{4}$. A major problem of a nickel catalyst is to deposit carbon species on the surface during the reaction, resulting in the deactivation of catalyst. It has been reported that the tendency of the carbon deposition is closely related to the type of a support used and the dispersion and size of nickel particles on support. ${ }^{1,2}$ To develop a coke-resistant nickel catalyst various metal oxides have been examined as the support of the $\mathrm{Ni}$ catalyst. Lanthanum sesquioxide as a support of a nickel catalyst is known to be a particularly effective component in reducing the carbon deposition. ${ }^{3,4}$ It has been reported that $\mathrm{La}_{2} \mathrm{O}_{3}$ can suppress the carbon deposition on the surface and the aggregation of nickel crystallites during the reforming reaction, leading to the enhancement of the catalyst stability. ${ }^{5-8}$

Supported metal catalysts are generally prepared by the conventional impregnation method. However, this method often fails to reproduce the catalyst and may give rise to the poor dispersion of metal particles on the support. One promising method for the preparation of well-dispersed nickel particles has been proposed by Takehira group, 9,10 called "solid phase crystallization method". In this method, metal-containing complex oxides are utilized as metal precursors. In recent, well-dispersed nickel particles on $\mathrm{La}_{2} \mathrm{O}_{3}$ have been successfully prepared by using $\mathrm{LaNiO}_{3}$ or $\mathrm{La}_{2} \mathrm{NiO}_{4}$ perovskite oxide as a starting material and the resulting $\mathrm{Ni} /$ $\mathrm{La}_{2} \mathrm{O}_{3}$ catalyst has been proved to be highly active and stable in the reforming reaction. ${ }^{4,11}$

Catalytic performances of $\mathrm{Ni} / \mathrm{La}_{2} \mathrm{O}_{3}$ for the reforming reaction have been largely studied. ${ }^{12-14}$ However, little kinetic data for the catalytic reaction have been reported so far. ${ }^{8,15}$ Although empirical kinetic data do not directly provide the accurate information of the reaction mechanism, kinetic information about the catalytic reaction is essential to understand the reaction mechanism. The most important consideration in the kinetic study is to monitor the concentration of reactants and/or products of interest as a function of time. We have shown previously that photoacoustic spectroscopy (PAS) is a suitable technique for in situ monitoring of the initial stage reaction processes. ${ }^{16,17}$ Since the PAS technique provides highly selective detection and extremely low molecular gas level detection, the signals with enough intensity can be obtained for even time-resolved experiments. ${ }^{18,19}$ 
The photoacoustic signals are directly related to the concentration of samples of interest, which allows this method to measure a temporal variation in concentration at short period of reaction times where rates are high.

In this work, $\mathrm{LaNiO}_{3}$ perovskite-type oxide was synthesized by a citrate sol-gel method. The oxide was reduced in a flow of $\mathrm{H}_{2}$ to form nickel metal particles dispersed on lanthanum oxide particles, so that the resulting product was examined as a catalyst for the $\mathrm{CO}_{2}$ reforming of $\mathrm{CH}_{4} \cdot \mathrm{A} \mathrm{CO}_{2}$ laser-based photoacoustic technique with a differential photoacoustic cell was employed to analyze kinetically the $\mathrm{CO}_{2}-\mathrm{CH}_{4}$ reaction over $\mathrm{Ni} / \mathrm{La}_{2} \mathrm{O}_{3}$ catalyst. The photoacoustic experiments were performed using a static reactor in the temperature range of $550-700{ }^{\circ} \mathrm{C}$ at various partial pressures of $\mathrm{CO}_{2}$ and $\mathrm{CH}_{4}$. The changes in the concentration of $\mathrm{CO}_{2}$ during the catalytic reaction were measured as a function of time. Rates of $\mathrm{CO}_{2}$ consumption in early reaction stage were obtained from the $\mathrm{CO}_{2}$ photoacoustic data. The apparent activation energy and reaction orders were determined from the initial rates of $\mathrm{CO}_{2}$ consumption. The conversion of reactants and the ratio of $\mathrm{H}_{2} / \mathrm{CO}$ were also measured in a flow reactor in the temperature range of $500-800{ }^{\circ} \mathrm{C}$ using an on-line gas chromatography system. The kinetic data obtained in this work were compared with others reported previously. A reaction mechanism of the $\mathrm{CO}_{2}-\mathrm{CH}_{4}$ reaction over the $\mathrm{Ni} / \mathrm{La}_{2} \mathrm{O}_{3}$ catalyst was then discussed from the kinetic results.

\section{Experimental}

Catalyst Preparation. $\mathrm{LaNiO}_{3}$ perovskite-type oxide was prepared from $\mathrm{La}\left(\mathrm{NO}_{3}\right)_{3} \cdot 6 \mathrm{H}_{2} \mathrm{O}(>99.99 \%$, Aldrich-Sigma) and $\mathrm{Ni}\left(\mathrm{NO}_{3}\right)_{2} \cdot 6 \mathrm{H}_{2} \mathrm{O},(>99.99 \%$, Aldrich-Sigma). Both the lanthanum nitrate and nickel nitrate were weighed to yield the desired mole ratio of $\mathrm{La} / \mathrm{Ni}$ and were then dissolved in deionized water. The resulting solution was mixed with an aqueous solution of citric acid to have the same amount of equivalents. Water was slowly evaporated from the mixed solution at $70{ }^{\circ} \mathrm{C}$ in vacuum until a viscous gel was formed. The viscous gel was kept at $100{ }^{\circ} \mathrm{C}$ overnight to produce a solid amorphous mixture. The resultant amorphous mixture was ground and calcined at $400{ }^{\circ} \mathrm{C}$. Further calcination was made at $600{ }^{\circ} \mathrm{C}$ to eliminate carbon species remaining in the sample and then cooled to room temperature at $60{ }^{\circ} \mathrm{C} / \mathrm{h}$ rate. The product was reduced in a flow of $\mathrm{H}_{2}$ at $700{ }^{\circ} \mathrm{C}$ for $3 \mathrm{~h}$ and further heated at $700{ }^{\circ} \mathrm{C}$ for $1 \mathrm{~h}$ in a flow of $\mathrm{He}$, which was followed by cooling to room temperature and ground in an agate mortar. These processes were then repeated three times to form nickel metal particles. X-ray powder diffraction analyses for the samples were conducted by using a Bruker D2 Phaser diffractometer with $\mathrm{Cu}-\mathrm{K}_{\alpha}$ radiation at room temperature. EDX (energy dispersive X-ray) analyses were performed for the $\mathrm{LaNiO}_{3}$ perovskite oxide using an Oxford Link ISIS 300 spectrometer. FE-SEM (Field emissionscanning electron micrograph) images of catalyst were obtained with a Hitachi SU70.

Kinetic Measurements. The catalytic reaction rate in the reforming reaction was measured by using the $\mathrm{CO}_{2}$ laserbased photoacoustic technique. The experimental arrangement for the photoacoustic detection method was described in previous paper. ${ }^{17,19}$ The catalytic reaction was carried out in a closed-circulating reactor system, where the reactor was made of a quartz tubing with a volume of $21 \mathrm{~cm}^{3}$. The reactor was placed in an electric furnace and directly connected to a differential photoacoustic cell by an adjoining tube. The differential photoacoustic cell was consisted of a sample cell and a reference cell, separated from each other by a $\mathrm{ZnSe}$ window. Each photoacoustic cell was a Helmholtz resonator of $1.9 \mathrm{~cm}$ in diameter and $3.3 \mathrm{~cm}$ in length with an adjoining tube of $1.1 \mathrm{~cm}$ in diameter and $2.8 \mathrm{~cm}$ in length, where microphones were located at the ends of the adjoining tubes. The output beam of a cw $\mathrm{CO}_{2}$ laser (Synrad Series 48-1-28) operating in multilines of $10.6 \mu \mathrm{m}$ was modulated at the nonresonance condition of $25 \mathrm{~Hz}$. The signals were detected by the microphones in both the sample (signal A) and reference (signal B) cells and amplified by a lock-in amplifier (EG \& G Princeton Applied Research Model 5210). The signal ratio $(\mathrm{A} / \mathrm{B})$ was then recorded as a function of time by using a personal computer. The total pressure of gaseous reactants in the reactor was maintained at 40 Torr filled with $\mathrm{N}_{2}$ as a buffer gas. The reference cell (signal B) was filled with a mixture of $\mathrm{CO}_{2}$ (0.2 Torr) and $\mathrm{N}_{2}$ (39.8 Torr) and the sample cell (signal A) was connected to the reactor loaded with the catalyst $(200 \mathrm{mg})$. The gaseous reaction mixture $\left(\mathrm{CO}_{2} / \mathrm{CH}_{4} / \mathrm{N}_{2}\right)$ was introduced into the reactor at a given temperature. The purity of gases was greater than $99.99 \%$ and the gases were dehydrated with suitable filters.

Conversions of reactants and ratio of $\mathrm{H}_{2} / \mathrm{CO}$ in the $\mathrm{CO}_{2}$ $\mathrm{CH}_{4}$ reaction over the $\mathrm{Ni} / \mathrm{La}_{2} \mathrm{O}_{3}$ catalyst were measured in a fixed-bed type flow reactor in the temperature range of 500$800{ }^{\circ} \mathrm{C}$ at atmospheric pressure. The reactor was quartz tubing with a $0.8-\mathrm{cm}-$ i.d. and $3-\mathrm{cm}$-long tube sealed to $0.4-\mathrm{cm}-$ i.d. tubes on two ends. The catalyst $(200 \mathrm{mg})$ was well dispersed on a fused-silica bed placed in the middle of the reactor which was kept in an electric furnace. The feed flow rate at ambient conditions was $5 / 5 / 20 \mathrm{~cm}^{3} / \mathrm{min}\left(\mathrm{CH}_{4} / \mathrm{CO}_{2} /\right.$ $\mathrm{Ar}$ ) and the flow rates of gases were controlled by electronic mass flow controllers. The gaseous reactants and products were analyzed by using an on-line gas chromatography with a thermal conductivity detector. A cold trap was placed at the reactor exit to remove water vapor from the gaseous mixture. $\mathrm{CH}_{4}, \mathrm{CO}_{2}$, and $\mathrm{CO}$ gases were analyzed by a gas chromatography using $\mathrm{He}$ carrier gas and $\mathrm{H}_{2}$ gas was separately analyzed by a gas chromatography using $\mathrm{Ar}$ carrier gas. The $\mathrm{CO}_{2}$ and $\mathrm{CH}_{4}$ conversions were calculated on the basis of the formula; conversion $(\%)=100 \times\left[\mathrm{F}_{\text {in }}-\right.$ $\left.F_{\text {out }}\right] / F_{\text {in }}$, where $F_{\text {in }}$ and $F_{\text {out }}$ were inlet and outlet flow rate of each reactant, respectively. The conversions were typically compared at $0.5 \mathrm{~h}$ time-on-stream.

\section{Results and Discussion}

The XRD pattern of the $\mathrm{LaNiO}_{3}$ sample synthesized by the citrate sol-gel method is displayed in Figure 1(a). The 


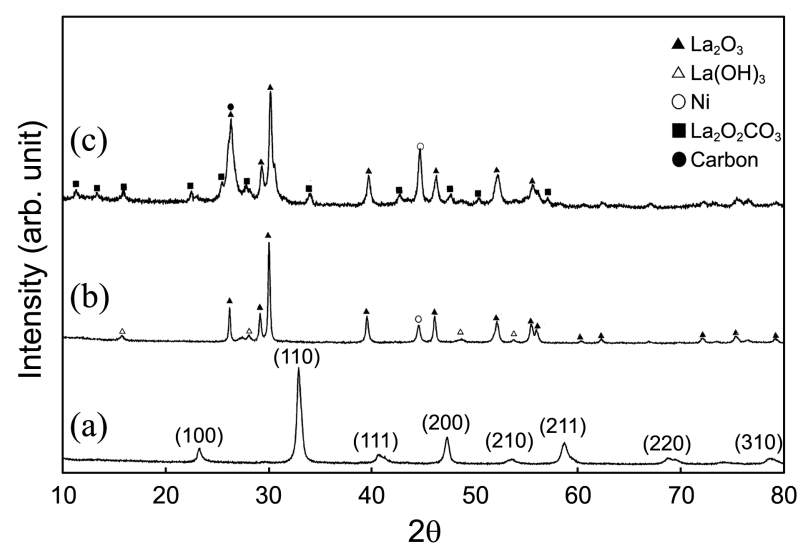

Figure 1. XRD patterns of (a) $\mathrm{LaNiO}_{3}$ prepared by citrate sol-gel method, (b) $\mathrm{Ni} / \mathrm{La}_{2} \mathrm{O}_{3}$ catalyst obtained by reduction of $\mathrm{LaNiO}_{3}$, and (c) $\mathrm{Ni} / \mathrm{La}_{2} \mathrm{O}_{3}$ catalyst after activity test at $700{ }^{\circ} \mathrm{C}$.

$\mathrm{LaNiO}_{3}$ was found to be monophase perovskite-type oxide possessing a rhombohedra structure (JCPDF 33-0711). Ni/ $\mathrm{La}$ atomic ratio in $\mathrm{LaNiO}_{3}$ was determined to be 1.02 from the K-lines obtained by EDX analysis. The XRD pattern of the $\mathrm{H}_{2}$-reduced $\mathrm{LaNiO}_{3}$ is shown in Figure 1(b), in which $\mathrm{La}_{2} \mathrm{O}_{3}$ (JCPDF 5-0562) and Ni metal with (111) preferential plane of a cubic structure (JCPDF 87-0712) are observed as a major phase and $\mathrm{La}(\mathrm{OH})_{3}(\mathrm{JCPDF} 36-1481)$ as a minor phase. This result indicates that the $\mathrm{LaNiO}_{3}$ oxide is completely decomposed into $\mathrm{La}_{2} \mathrm{O}_{3}$ and $\mathrm{Ni}^{0}$ under the reducing conditions. Accordingly, the $\mathrm{H}_{2}$-reduced $\mathrm{LaNiO}_{3}$ sample corresponds to $26.5 \mathrm{wt} \% \mathrm{Ni} / \mathrm{La}_{2} \mathrm{O}_{3}$. Figure 1 (c) shows the XRD pattern of the $\mathrm{Ni} / \mathrm{La}_{2} \mathrm{O}_{3}$ catalyst after the activity test for the reforming reaction at $700{ }^{\circ} \mathrm{C}$ in a flow reactor, which reveals the presence of carbon solid (JCPDF 75-1621) and $\mathrm{La}_{2} \mathrm{O}_{2} \mathrm{CO}_{3}$ (JCPDF 37-0804 and 48-1113) phases. A FESEM image of the $\mathrm{Ni} / \mathrm{La}_{2} \mathrm{O}_{3}$ catalyst is displayed in Figure 2, showing well-dispersed nickel metal crystallites and lanthanum oxide particles.

The rates of the $\mathrm{CO}_{2}$ consumption in early reaction stage for the reforming reaction were measured by the $\mathrm{CO}_{2}$ laserbased photoacoustic technique. As mentioned above, the PAS technique is applicable to the quantitative analysis by

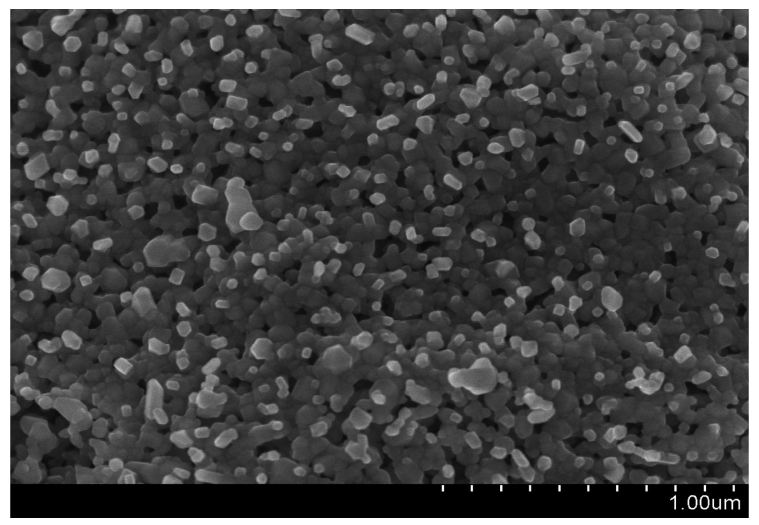

Figure 2. FE-SEM image of $\mathrm{Ni} / \mathrm{La}_{2} \mathrm{O}_{3}$ sample obtained by reduction of $\mathrm{LaNiO}_{3}$.

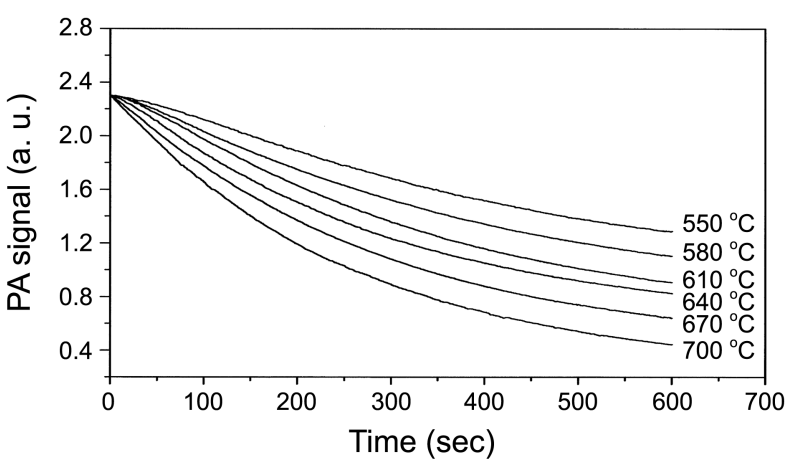

Figure 3. Variations of $\mathrm{CO}_{2}$ photoacoustic signal with time at various temperatures for $\mathrm{CO}_{2}-\mathrm{CH}_{4}$ reaction over $\mathrm{Ni} / \mathrm{La}_{2} \mathrm{O}_{3}$ catalyst: $\mathrm{CO}_{2} / \mathrm{CH}_{4} / \mathrm{N}_{2}=7 / 7 / 26$ in Torr, catalyst weight $=200 \mathrm{mg}$.

monitoring the progress of the reaction because the photoacoustic signal is directly proportional to the concentration of reaction analytes under a given conditions. The $\mathrm{CO}_{2}$ photoacoustic signal was found to show an optimal linearity and response of the signal under conditions of $\mathrm{CO}_{2}$ laser power ranging of 1-8 $\mathrm{W}$ and $\mathrm{CO}_{2}$ partial pressures below 10 Torr. Accordingly, the PAS measurements were conducted under $\mathrm{CO}_{2}$ partial pressure below 10 Torr at a $\mathrm{CO}_{2}$ laser power of $1.5 \mathrm{~W}$. A blank test, performed with a $\mathrm{CO}_{2} / \mathrm{CH}_{4} / \mathrm{N}_{2}$ $(5 / 5 / 30$ in Torr) mixture in the absence of catalyst, showed no variations of the $\mathrm{CO}_{2}$ photoacoustic signal in the temperature range of $550-700{ }^{\circ} \mathrm{C}$. Thus, the effect of temperature on the rate of $\mathrm{CO}_{2}$ consumption for the $\mathrm{CO}_{2}-\mathrm{CH}_{4}$ reaction over the $\mathrm{Ni} / \mathrm{La}_{2} \mathrm{O}_{3}$ was investigated using $\mathrm{CO}_{2} / \mathrm{CH}_{4} / \mathrm{N}_{2}(5 / 5 / 30$ in Torr) mixture in the temperature range of $550-700{ }^{\circ} \mathrm{C}$. In Figure 3 is displayed the variations of the $\mathrm{CO}_{2}$ photoacoustic signal with time for the reforming reaction at various temperatures. As observed in Figure 3, the $\mathrm{CO}_{2}$ photoacoustic signals gradually decrease with time in the reaction period up to $600 \mathrm{~s}$. The rates of the $\mathrm{CO}_{2}$ consumption were estimated from the photoacoustic signal data in the early reaction period of 0-50 $\mathrm{s}$. The rates were then plotted as a function of reciprocal temperature according to the Arrhenius-type equation. As displayed in Figure 4, the curve shows linear lines below and above $610^{\circ} \mathrm{C}$. The apparent activation energies for the $\mathrm{CO}_{2}$ consumption, calculated from the slope of each curve, were $10.4 \mathrm{kcal} / \mathrm{mol}$ for the low temperature

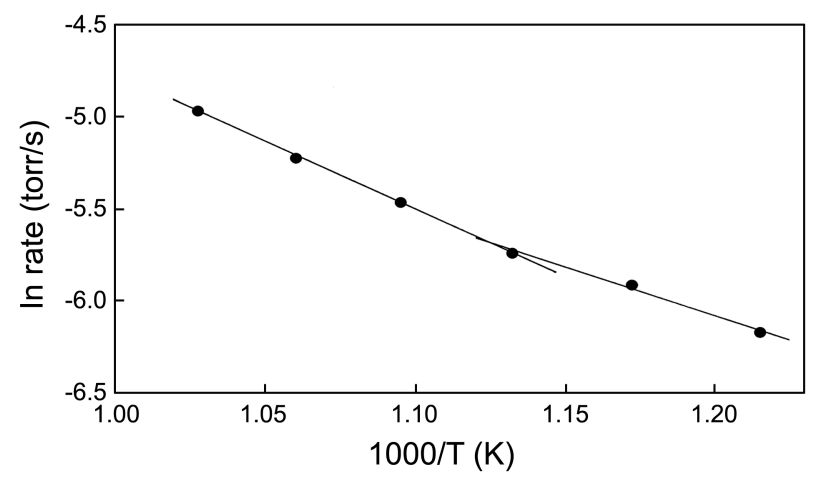

Figure 4. Influence of temperature on rate of $\mathrm{CO}_{2}$ disappearance for $\mathrm{CO}_{2}-\mathrm{CH}_{4}$ reaction over $\mathrm{Ni} / \mathrm{La}_{2} \mathrm{O}_{3}$ catalyst: $\mathrm{CO}_{2} / \mathrm{CH}_{4} / \mathrm{N}_{2}=7 / 7 /$ 26 in Torr, catalyst weight $=200 \mathrm{mg}$. 

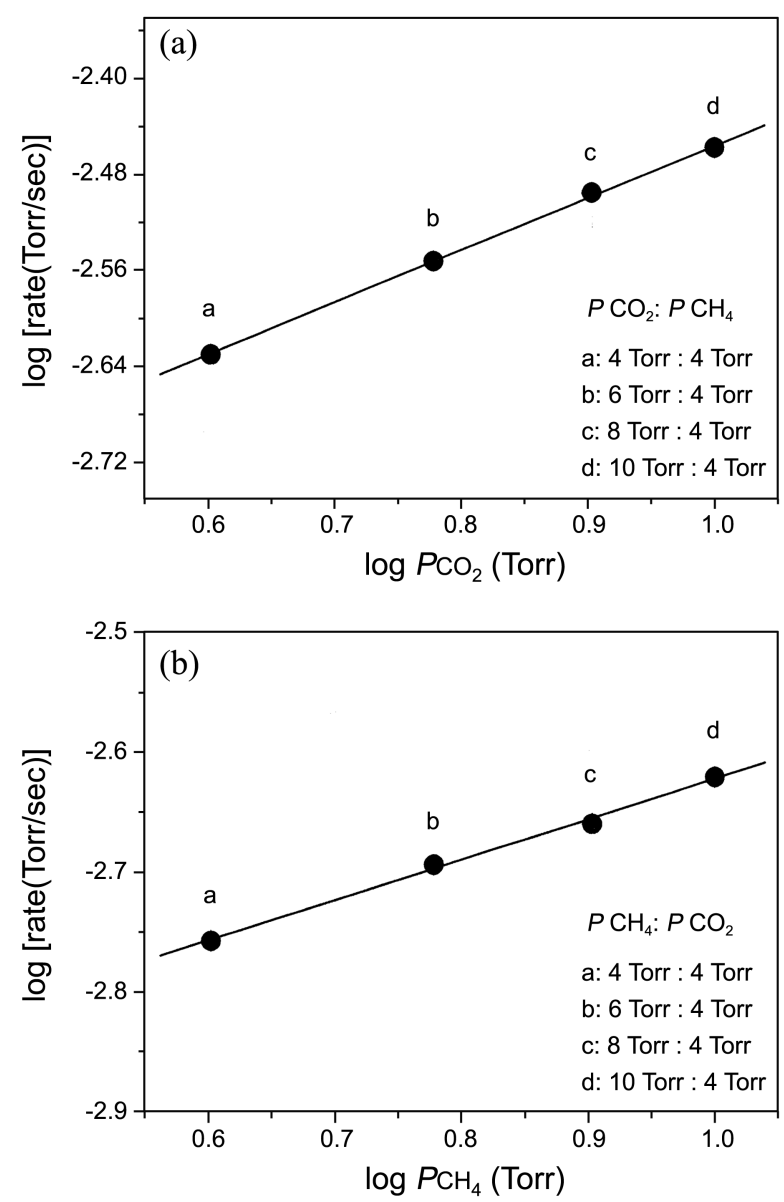

Figure 5. (a) $P_{\mathrm{CO}_{2}}$ dependence and (b) $P_{\mathrm{CH}_{4}}$ dependence of $\mathrm{CO}_{2}$ disappearance rate at $640{ }^{\circ} \mathrm{C}$ for $\mathrm{CO}_{2}-\mathrm{CH}_{4}$ reaction over $\mathrm{Ni} / \mathrm{La}_{2} \mathrm{O}_{3}$ catalyst.

region $\left(550-610^{\circ} \mathrm{C}\right)$ and $14.6 \mathrm{kcal} / \mathrm{mol}$ for the high temperature region $\left(610-700{ }^{\circ} \mathrm{C}\right)$. To investigate the pressure dependence of the $\mathrm{CO}_{2}$ consumption rate for the reforming reaction, the $\mathrm{CO}_{2}$ photoacoustic signals were recorded under various partial pressures of $\mathrm{CO}_{2}$ and $\mathrm{CH}_{4}, P_{\mathrm{CO}_{2}}$ and $P_{\mathrm{CH}_{4}}$, at $640{ }^{\circ} \mathrm{C}$. The initial rates obtained from the $\mathrm{CO}_{2}$ photoacoustic data were plotted as a function of $P_{\mathrm{CO}_{2}}$ and $P_{\mathrm{CH}_{4}}$, respectively, according to the power rate law, rate $=k\left(P_{\mathrm{CO}_{2}}\right)^{m}\left(P_{\mathrm{CH}_{4}}\right)^{n}$. Figure 5 shows the $P_{\mathrm{CO}_{2}}$ and $P_{\mathrm{CH}_{4}}$ dependences of the rate of $\mathrm{CO}_{2}$ consumption for the reforming reaction. The reaction orders, determined from the slope of the curves, were 0.43 with respect to $\mathrm{CO}_{2}$ and 0.33 with respect to $\mathrm{CH}_{4}$.

Figure 6 shows the variations of conversions and the ratio of $\mathrm{H}_{2} / \mathrm{CO}$ with temperatures for the $\mathrm{CO}_{2}-\mathrm{CH}_{4}$ reaction over $\mathrm{Ni} / \mathrm{La}_{2} \mathrm{O}_{3}$ catalyst in the temperature range of $500-800^{\circ} \mathrm{C}$, which was measured in a flow of $\mathrm{CH}_{4} / \mathrm{CO}_{2} / \mathrm{Ar}\left(5 / 5 / 20 \mathrm{~cm}^{3} /\right.$ $\mathrm{min}$ ) mixture at $1 \mathrm{~atm}$. As shown in Figure 6 , the $\mathrm{CO}_{2}$ conversion is nearly equal to the $\mathrm{CH}_{4}$ conversion below $550{ }^{\circ} \mathrm{C}$, but in the temperature range of $600-750{ }^{\circ} \mathrm{C}$ the $\mathrm{CO}_{2}$ conversion is somewhat lower than the $\mathrm{CH}_{4}$ conversion. Note that at $800^{\circ} \mathrm{C}$ both the conversions reach to almost $100 \%$. The ratios of $\mathrm{H}_{2} / \mathrm{CO}$ were found to vary with temperature between 0.66 and 1.0 ; less than 1 at $500{ }^{\circ} \mathrm{C}$ and $550^{\circ} \mathrm{C}$, close to 1 at $600{ }^{\circ} \mathrm{C}$ and $650{ }^{\circ} \mathrm{C}$, and less than 1 above
$700{ }^{\circ} \mathrm{C}$.

Because only limited kinetic data for the rates of the $\mathrm{CO}_{2}$ consumption have been reported previously, it is difficult to compare the present data directly with others. According to the kinetic results reported previously for the nickel-catalyzed $\mathrm{CO}_{2}-\mathrm{CH}_{4}$ reaction, ${ }^{20}$ the apparent activation energies for the $\mathrm{CO}_{2}$ consumption, varying with the supports used, are in the range of $8-22 \mathrm{kcal} / \mathrm{mol}$, noting that our values fall in the range. Tsipouriari and Verykios ${ }^{15}$ measured the rates of the $\mathrm{CO}$ formation for the $\mathrm{CO}_{2}-\mathrm{CH}_{4}$ reaction over $17 \mathrm{wt} \% \mathrm{Ni} /$ $\mathrm{La}_{2} \mathrm{O}_{3}$ catalyst in a flow reactor in the temperature range of $650-750{ }^{\circ} \mathrm{C}$. They determined the apparent activation energy to be $13.2 \mathrm{kcal} / \mathrm{mol}$ of which value is close to the one in the present experiment, $14.6 \mathrm{kcal} / \mathrm{mol}$, obtained in the temperature range of $610-700^{\circ} \mathrm{C}$. In the previous work, ${ }^{16}$ we performed kinetic studies of the reforming reactions over $\mathrm{Ni}$ / $\mathrm{TiO}_{2}$ and $\mathrm{Ni} / \mathrm{Al}_{2} \mathrm{O}_{3}$ catalysts using a PAS technique. From the $\mathrm{CO}_{2}$ consumption rates measured in the temperature range of $400-650{ }^{\circ} \mathrm{C}$, the apparent activation energies were determined to be $14.3 \mathrm{kcal} / \mathrm{mol}$ for $\mathrm{Ni} / \mathrm{TiO}_{2}$ catalyst and 15.4 $\mathrm{kcal} / \mathrm{mol}$ for $\mathrm{Ni} / \mathrm{Al}_{2} \mathrm{O}_{3}$ catalyst. These values are close to $14.6 \mathrm{kcal} / \mathrm{mol}$ obtained in the temperature range of $610-$ $700{ }^{\circ} \mathrm{C}$ in this work. Figure 5 shows that the $\mathrm{CO}_{2}$ consumption rate depends on the $P_{\mathrm{CO}_{2}}$ and $P_{\mathrm{CH}_{4}}$, in which the reaction order to $\mathrm{CO}_{2}, 0.43$, is somewhat higher than the reaction order to $\mathrm{CH}_{4}, 0.33$. The reaction orders are also difficult to compare directly with others because partial orders determined from the $\mathrm{CO}_{2}$ consumption rates for the $\mathrm{Ni} / \mathrm{La}_{2} \mathrm{O}_{3}$ catalyzed reforming reaction have not been reported. According to Tsipouriari and Verykios, ${ }^{15}$ the rate of the $\mathrm{CH}_{4}$ consumption for the $\mathrm{CO}_{2}-\mathrm{CH}_{4}$ reaction over $\mathrm{Ni} / \mathrm{La}_{2} \mathrm{O}_{3}$ catalyst in the temperature range of $650-750{ }^{\circ} \mathrm{C}$ is more sensitive to $P_{\mathrm{CO}_{2}}$ than to $P_{\mathrm{CH}_{4}}$ at low partial pressures below 75 Torr, which is considered to be in agreement with our results.

The $\mathrm{CO}_{2}-\mathrm{CH}_{4}$ reforming reaction is highly endothermic and is favored by low pressure and high temperature. Various reaction models for the reforming reaction have been suggested during the last twenty years. Although there are some disagreements in the reaction mechanism, it is generally accepted that both $\mathrm{CH}_{4}$ and $\mathrm{CO}_{2}$ are dissociatively chemisorbed on nickel metal surface. Erdöhelyi et $a .^{21}$ and Rostrup-Nielson et $a .^{22}$ have suggested that methane is dissociatively adsorbed on nickel surface, $\mathrm{CH}_{4}(\mathrm{~g}) \rightleftarrows \mathrm{CH}_{\mathrm{x}}$ (ads) $+(4-\mathrm{x}) \mathrm{H}(\mathrm{ads})$, and the $\mathrm{CO}_{2}$ dissociation can be promoted by the $\mathrm{H}$ (ads). Bradford and Vannice ${ }^{20}$ have proposed that surface $\mathrm{CH}_{\mathrm{x}}(\mathrm{ads})$ fragments react with either oxygen atoms or hydroxyl groups to form a formate-type $\mathrm{CH}_{\mathrm{x}} \mathrm{O}$ intermediate which subsequently decomposes into $\mathrm{CO}$ and $\mathrm{H}_{2}$ products. Zhang et al. ${ }^{23}$ have suggested from the FT-IR and XPS results for $\mathrm{Ni} / \mathrm{La}_{2} \mathrm{O}_{3}$-catalyzed $\mathrm{CO}_{2}-\mathrm{CH}_{4}$ reaction at $750{ }^{\circ} \mathrm{C}$ that a formate-type $\mathrm{HCOO}^{-}$intermediate is initially formed and subsequently reacts with $\mathrm{H}^{+}(\mathrm{ads})$ to yield $\mathrm{H}_{2} \mathrm{O}$ and CO.

If formate-type species are intermediates in the reaction mechanism, the rate of the $\mathrm{CO}_{2}$ consumption should be closely related to the adsorption of $\mathrm{CH}_{4}$ on the surface..$^{22,23}$ As is observed in the current study, the $\mathrm{CO}_{2}$ consumption 

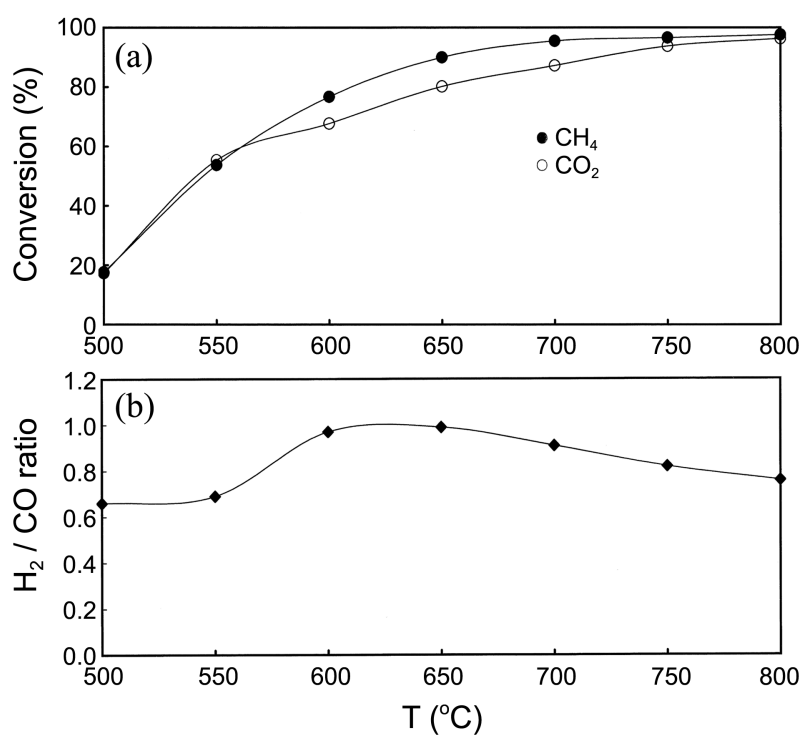

Figure 6. (a) Conversions and (b) ratio of $\mathrm{H}_{2} / \mathrm{CO}$ at various temperatures for $\mathrm{CO}_{2}-\mathrm{CH}_{4}$ reaction over $\mathrm{Ni} / \mathrm{La}_{2} \mathrm{O}_{3}$ catalyst: $\mathrm{CO}_{2} /$ $\mathrm{CH}_{4} / \mathrm{Ar}=5 / 5 / 20 \mathrm{~cm}^{3} / \mathrm{min}$, catalyst weight $=200 \mathrm{mg}$.

rate is dependent on the $P_{\mathrm{CH}_{4}}$. In order to form formate-type intermediates, oxygen atoms must be provided from $\mathrm{CO}_{2}$ acting as a potential oxidant. It is well known that $\mathrm{CO}_{2}$ participates in the reaction mechanism through the reverse water-gas shift reaction to form surface $\mathrm{OH}$ groups which react with $\mathrm{CH}_{\mathrm{x}}(\mathrm{ads})$ to form formate-type intermediates. ${ }^{15}$ Note that the reverse water-gas shift reaction, $\mathrm{CO}_{2}(\mathrm{~g})+$ $\mathrm{H}_{2}(\mathrm{~g}) \rightarrow \mathrm{H}_{2} \mathrm{O}(\mathrm{g})+\mathrm{CO}(\mathrm{g})$, occurs below $820^{\circ} \mathrm{C}$. If the reverse water-gas shift reaction is favorable as a side reaction, the ratio of $\mathrm{H}_{2} / \mathrm{CO}$ would be lower than 1. In Figure 6, the $\mathrm{H}_{2} /$ $\mathrm{CO}$ ratios at 500 and $550{ }^{\circ} \mathrm{C}$, measured in a flow reactor with $\mathrm{CH}_{4} / \mathrm{CO}_{2} / \mathrm{Ar}$ mixture $\left(5 / 5 / 20 \mathrm{~cm}^{3} / \mathrm{min}\right)$, are lower than 1 , where the $\mathrm{CO}_{2}$ conversion is nearly equal to the $\mathrm{CH}_{4}$ conversion. This result suggests the occurrence of the reverse watergas shift reaction as a side reaction at these temperatures.

On the other hand, the $\mathrm{H}_{2} / \mathrm{CO}$ ratios measured at 600 and $650{ }^{\circ} \mathrm{C}$ are close to 1 , where the conversion of $\mathrm{CO}_{2}$ is lower than $\mathrm{CH}_{4}$ as shown in Figure 6. The result implies that other side reactions may occur at the temperatures. Under the conditions of stoichiometric $\mathrm{CO}_{2}-\mathrm{CH}_{4}$ reaction, both the $\mathrm{CO}$ disproportionation $\left(2 \mathrm{CO}(\mathrm{g}) \rightarrow \mathrm{C}(\mathrm{s})+\mathrm{CO}_{2}(\mathrm{~g})\right)$ and the methane cracking $\left(\mathrm{CH}_{4}(\mathrm{~g}) \rightarrow \mathrm{C}(\mathrm{g})+2 \mathrm{H}_{2}(\mathrm{~g})\right)$ can be considered as side reactions. From the viewpoint of thermochemistry, the $\mathrm{CO}$ disproportionation occurs below $700{ }^{\circ} \mathrm{C}$ at $1 \mathrm{~atm}$ and the methane cracking occurs above $560^{\circ} \mathrm{C}$ at $1 \mathrm{~atm}$. When both the reactions as side reactions favorably occur in the temperature range of $600-650{ }^{\circ} \mathrm{C}$, the $\mathrm{CO}_{2}$ conversion would be lower than the $\mathrm{CH}_{4}$ conversion and then the $\mathrm{H}_{2} / \mathrm{CO}$ ratios would increase with temperature. As observed in Figure 6, the $\mathrm{H}_{2} / \mathrm{CO}$ ratios at $600{ }^{\circ} \mathrm{C}$ and $650{ }^{\circ} \mathrm{C}$ are greater than those below $550^{\circ} \mathrm{C}$. Both the $\mathrm{CO}$ disproportionation and the methane cracking produce carbon species, which can give rise to the catalytic deactivation. In Figure 1, the XRD pattern of the $\mathrm{Ni} / \mathrm{La}_{2} \mathrm{O}_{3}$ catalyst after the activity test at $700{ }^{\circ} \mathrm{C}$ exhibits the presence of carbon phase, indicating that carbon is deposited during the reforming reaction. The $\mathrm{CO}$ disproportionation reaction is exothermic $\left(\Delta \mathrm{H}^{\circ}=-41.2 \mathrm{kcal} / \mathrm{mol}\right)$, while the methane cracking is endothermic $\left(\Delta \mathrm{H}^{0}=+17.9\right.$ $\mathrm{kcal} / \mathrm{mol}$ ). Accordingly, it is expected that the methane cracking is more favorable at higher temperatures. When the methane cracking occurs favorably at higher temperatures, the catalyst would be rapidly deactivated by the carbon deposition during the reforming reaction.

Carbon species deposited on the surface of Ni catalyst, which can serve as intermediates in the reforming reaction, are known to be highly reactive. ${ }^{24,25}$ The surface carbon can readily react with $\mathrm{H}_{2} \mathrm{O}(\mathrm{g})$ and $\mathrm{CO}_{2}(\mathrm{~g})$ to form $\mathrm{H}_{2}, \mathrm{CO}$, and $\mathrm{CO}_{2}$ according to the following processes; $\mathrm{C}(\mathrm{s})+\mathrm{H}_{2} \mathrm{O}(\mathrm{g}) \rightarrow$ $\mathrm{CO}(\mathrm{g})+\mathrm{H}_{2}(\mathrm{~g}), \mathrm{C}(\mathrm{s})+2 \mathrm{H}_{2} \mathrm{O}(\mathrm{g}) \rightarrow \mathrm{CO}_{2}(\mathrm{~g})+2 \mathrm{H}_{2}(\mathrm{~g}), \mathrm{C}(\mathrm{s})+$ $\mathrm{CO}_{2}(\mathrm{~g}) \rightarrow 2 \mathrm{CO}(\mathrm{g})$. These reactions, called the gasification of carbon solid, can occur above $700{ }^{\circ} \mathrm{C}$ at $1 \mathrm{~atm}$ and can be promoted by nickel. ${ }^{26.27}$ In Figure 6, the $\mathrm{H}_{2} / \mathrm{CO}$ ratio is found to be less than 1 above $700{ }^{\circ} \mathrm{C}$ and decreases with increasing temperature. This suggests that the $\mathrm{CO}_{2}$ gasification of carbon solid may be more favorable. The $\mathrm{CO}_{2}$ consumption in the side reaction, $\mathrm{C}(\mathrm{s})+\mathrm{CO}_{2}(\mathrm{~g}) \rightarrow 2 \mathrm{CO}(\mathrm{g})$, would give rise to larger change in the total $\mathrm{CO}_{2}$ photoacoustic signal during the reforming reaction, resulting in the observation of higher apparent activation energy for the $\mathrm{CO}_{2}$ consumption. It is also notable that the $\mathrm{C}(\mathrm{s})-\mathrm{CO}_{2}(\mathrm{~g})$ reaction is expected to be more favorable at lower pressures. As shown in Figure 4, the apparent activation energy obtained for the high temperature region, $14.6 \mathrm{kcal} / \mathrm{mol}$, is higher than that for the low temperature region, $10.4 \mathrm{kcal} / \mathrm{mol}$, which is enable us to consider that the $\mathrm{C}(\mathrm{s})-\mathrm{CO}_{2}(\mathrm{~g})$ reaction occurs at high temperatures.

$\mathrm{La}_{2} \mathrm{O}_{3}$ oxide is known to be strongly basic and it is easily hydrated and carbonated when it is exposed to air. ${ }^{28}$ In Figure 3, the XRD pattern of the $\mathrm{Ni} / \mathrm{La}_{2} \mathrm{O}_{3}$ catalyst after the activity test at $700{ }^{\circ} \mathrm{C}$ shows the presence of lanthanum dioxycarbonate, indicating that $\mathrm{La}_{2} \mathrm{O}_{3}$ is carbonated to $\mathrm{La}_{2} \mathrm{O}_{2} \mathrm{CO}_{3}$ phase during the reforming reaction. When $\mathrm{La}_{2} \mathrm{O}_{3}$ is exposed to a mixture of water vapor and $\mathrm{CO}_{2}, \mathrm{La}_{2}(\mathrm{OH})_{4} \mathrm{CO}_{3}$ phase is formed and subsequently decomposes to $\mathrm{La}_{2} \mathrm{O}_{2} \mathrm{CO}_{3}$ around $460{ }^{\circ} \mathrm{C}$, which have been also identified as intermediate phases in the decomposition of lanthanum carbonate. ${ }^{28}$ Since $\mathrm{La}_{2} \mathrm{O}_{2} \mathrm{CO}_{3}$ phase decomposes around $630{ }^{\circ} \mathrm{C}$ at $1 \mathrm{~atm}, \mathrm{La}_{2} \mathrm{O}_{3}$ support is expected to be carbonated at surface levels during the reforming reaction at temperatures above $630{ }^{\circ} \mathrm{C}$. The carbonation of $\mathrm{La}_{2} \mathrm{O}_{3}$ by $\mathrm{CO}_{2}(\mathrm{~g})$ can be represented as $\mathrm{La}_{2} \mathrm{O}_{3}$ $+\mathrm{CO}_{2}(\mathrm{~g}) \rightleftarrows \mathrm{La}_{2} \mathrm{O}_{2} \mathrm{CO}_{3}$ or $\mathrm{La}_{2} \mathrm{O}_{3} \cdot\left(\mathrm{CO}_{2}\right)_{\text {ads }}$, which means that there is an equilibrium between $\mathrm{CO}_{2}(\mathrm{~g})$ and $\mathrm{CO}_{2}(\mathrm{ads})$. Rivas et al. ${ }^{11}$ and Zhang et al. ${ }^{29}$ have suggested that $\mathrm{La}_{2} \mathrm{O}_{2} \mathrm{CO}_{3}$ species at the interfacial area react with the carbon species deposited on the surface of nickel particles to produce two $\mathrm{CO}$ molecules. This indicates that the $\mathrm{La}_{2} \mathrm{O}_{2} \mathrm{CO}_{3}$ phase can play a major role in the catalytic stability. The carbon species can react with $\mathrm{CO}_{2}$ molecules adsorbed on $\mathrm{La}_{2} \mathrm{O}_{3}$ or released from $\mathrm{La}_{2} \mathrm{O}_{2} \mathrm{CO}_{3}$ to produce $\mathrm{CO}$. It is shown in Figure 6 that the $\mathrm{H}_{2} / \mathrm{CO}$ ratio decreases with temperature above $700{ }^{\circ} \mathrm{C}$. When the reaction between carbon and $\mathrm{CO}_{2}(\mathrm{~g}) / \mathrm{or} \mathrm{CO}_{2}(\mathrm{ads})$ favorably occurs during the reforming reaction, the ratio of 
$\mathrm{H}_{2} / \mathrm{CO}$ would be lower than 1 . In the early work of $\mathrm{Ni}$ / $\mathrm{Al}_{2} \mathrm{O}_{3}$ - and $\mathrm{Ni} / \mathrm{TiO}_{2}$-promoted $\mathrm{CO}_{2}-\mathrm{CH}_{4}$ reactions, ${ }^{16}$ the reaction orders determined from initial rates of the $\mathrm{CO}_{2}$ consumption at $600{ }^{\circ} \mathrm{C}$ were found to be 0.48 for $\mathrm{CH}_{4}$ and 0.45 for $\mathrm{CO}_{2}$ for the $\mathrm{Ni} / \mathrm{Al}_{2} \mathrm{O}_{3}$-promoted process, and 0.38 for $\mathrm{CH}_{4}$ and 0.32 for $\mathrm{CO}_{2}$ for the $\mathrm{Ni} / \mathrm{TiO}_{2}$-promoted process. This indicates that the reaction orders to $\mathrm{CH}_{4}$ are somewhat higher than to $\mathrm{CO}_{2}$. However, the dependence of the $\mathrm{CO}_{2}$ consumption rate to $\mathrm{CO}_{2}$, determined from initial rates of the $\mathrm{CO}_{2}$ consumption at $640{ }^{\circ} \mathrm{C}$ in this work, was observed to be somewhat higher than that to $\mathrm{CH}_{4}$. This result is considered to be due to the $\mathrm{C}(\mathrm{s})-\mathrm{CO}_{2}(\mathrm{~g})$ reaction (the reverse Boudouard reaction).

\section{Conclusion}

In this work, well-dispersed $\mathrm{Ni} / \mathrm{La}_{2} \mathrm{O}_{3}$ catalyst was prepared by the reduction of perovskite-type $\mathrm{LaNiO}_{3}$ and examined for the $\mathrm{CO}_{2}$ reforming of $\mathrm{CH}_{4}$. The $\mathrm{CH}_{4}$ and $\mathrm{CO}_{2}$ conversions measured in a flow reactor under atmospheric pressure showed the catalyst to be highly active for the reaction. The catalytic reaction was kinetically investigated in the temperature range of $550-700{ }^{\circ} \mathrm{C}$ at various partial pressures of $\mathrm{CO}_{2}$ and $\mathrm{CH}_{4}$ (40 Torr total pressure of $\mathrm{CO}_{2} /$ $\mathrm{CH}_{4} / \mathrm{N}_{2}$ ) in a static reactor system with the differential photoacoustic cell. Rates of $\mathrm{CO}_{2}$ disappearance were obtained by in situ monitoring the concentration changes of $\mathrm{CO}_{2}$ during the catalytic reaction. The apparent activation energy and the reaction orders were determined from the rates of the $\mathrm{CO}_{2}$ disappearance in the early reaction stage. A reaction mechanism for the $\mathrm{Ni} / \mathrm{La}_{2} \mathrm{O}_{3}$-catalyzed $\mathrm{CO}_{2}-\mathrm{CH}_{4}$ reaction could be deduced from the kinetic results in conjunction with the catalytic data obtained in a flow reactor. The kinetic data obtained for early reaction stages characterized by high reaction rates may be different from those for the later stages showing a constant catalytic activity. In addition, the kinetic measurement at high pressure could be more advantageous to the integrated kinetic analysis for the catalytic reaction because the reaction rate is directly linked to the surface coverage depending on the pressure of reaction gases. Nevertheless, it should pointed that the $\mathrm{CO}_{2}$ photoacoustic signal linearly varies with the concentration of $\mathrm{CO}_{2}$ in low molecular level detection at a low pressure environment and can be recorded as a function of time-on-stream during the catalytic process. This allows that the photoacoustic technique is considered as a suitable one for the molecular level study of the reaction kinetics at the early reaction stage in the catalytic $\mathrm{CO}_{2}-\mathrm{CH}_{4}$ reaction.

Acknowledgments. This research was supported by Basic
Science Research Program through the National Research Foundation of Korea (NRF) funded by the Ministry of Education, Science and Technology (NRF-2009-0072984 and NRF-2012R1A1A2005806).

\section{References}

1. Bartholomew, C. H. Catal. Rev.-Sci. Eng. 1982, 5, 67.

2. Tang, S.; Ji, L.; Lin, J.; Zeng, H. C.; Tan, K. L.; Li, K. J. Catal. 2000, 194, 424.

3. Tsipouriare, V. A.; Verykios, X. E. J. Catal. 1998, 179, 292.

4. Guo, C.; Zhang, X.; Zhang, J.; Wang, Y. J. Mole. Catal. A 2007, 269, 254.

5. Luo, J. Z.; Yu, Z. L.; Ng, C. F.; Au, C. T. J. Catal. 2000, 194, 198. 6. Ding, R. G.; Yan, Z. F. Catal. Taday 2001, 68, 135.

7. Xu, Z.; Li, Y. M.; Zhang, J. Y.; Chang, L.; Zhou, R. Q.; Duan, Z. T. Appl. Catal. A 2001, 210, 45.

8. Cui, Y.; Zhang, H.; Xu, H.; Li, W. Appl. Catal. A 2007, 331, 60.

9. Shiozaki, R.; Anderson, A. G.; Hayakawa, T.; Hamakawa, S.; Suzuki, K.; Shimizu, M.; Takehira, K. Stud. Surf. Sci. Catal. 1997, 110,701 .

10. Hayakawa, T.; Suzuki, S.; Nakamura, J.; Uchijima, T.; Hamakawa, S.; Suzuki, K.; Shishido, T.; Takehira, K. Appl. Catal. A 1999, 183, 273.

11. Rivas, M. E.; Fierro, J. L. G.; Goldwasser, M. R.; Pietri, E.; PérezZurita, M. J.; Griboval-Constant, A.; Ledereg, G. Appl. Catal. A 2008, 344, 10

12. Martinez, R.; Romero, E.; Guimon, C.; Bilbao, R. Appl. Catal. A 2004, 274, 139.

13. Batiot-Dupeyrat, C.; Valderrama, G.; Meneses, A.; Martinez, F.; Barrault, J.; Tatibouët, J. M. Appl. Catal. A 2003, 248, 143.

14. Zhang, Z.; Verykios, X. E.; MacDonald, S. M.; Affrossman, S. J. Phys. Chem. 1996, 100, 744.

15. Tsipouriari, V. A.; Vrykios, X. E. Catal. Today 2001, 64, 83.

16. Kim, J.-W.; Ha, J.-A.; Jung, H.; Ahn, B.-I.; Lee, S.-H.; Choi, J.-G. Phys. Chem. Chem. Phys. 2007, 9, 5828.

17. Jung, H.; Kim, J.-W.; Cho, Y.-G.; Jung, J.-S.; Lee, S.-H.; Choi, J.G. Appl. Catal. A 2009, 368, 50.

18. Choi, J. G.; Diebold, G. J. Anal. Chem. 1987, 59, 519.

19. Jung, H. J.; Lim, J. T.; Lee, S. H.; Kim, Y. R.; Choi, J. G. J. Phys. Chem. 1996, 100, 10243.

20. Bradford, M. C. J.; Vannice, M. A. Catal. Rev.-Sci. Eng. 1999, 41, 1 .

21. Erdöhelyi, A.; Cserenyi, J.; Papp, E.; Solymosi, F. Appl. Catal. A 1994, 108, 525.

22. Rostrup-Nielson, J. R.; Bak Hansen, J.-H. J. Catal. 1993, 144, 38.

23. Zhang, Z.; Verykios, X. E.; MacDonald, S. M.; Affrossman, S. J. Phys. Chem. 1996, 100, 744.

24. Bradford, M. C. J.; Vannice, M. A. Appl. Catal. A 1996, $142,97$.

25. Kroll, V. C. H.; Swaan, H. M.; Lacombe, S.; Mirodatos, C. J. Catal. 1997, 164, 387.

26. Wang, S.; Lu, G. Q.; Millar, G. J. Energy \& Fuels 1996, 10, 896.

27. Takenaka, S.; Kato, E.; Tomikubo, Y.; Otsuka, K. J. Catal. 2003 , 219, 176.

28. Bernal, S.; Botana, F. J.; Gaecia, R.; Rodriquez-Izquierdo, J. M. Reactivity of Solids 1987, 4, 23.

29. Zhang, W. D.; Liu, B. S.; Zhu, C.; Tian, Y. J. Appl. Catal. A 2005 , $292,138$. 